\title{
Peer-Based Education Regarding the COVID-19 Pandemic
}

\author{
Patrick W. Corrigan · Katherine Nieweglowski
}

Received: 15 June 2020/Accepted: 17 June 2020/Published online: 9 July 2020

(C) Springer Nature India Private Limited 2020

People with psychiatric disabilities show inordinate rates of co-occurring physical illnesses including morbidities in most major organ systems that may cause them to die 15-30 years younger than their same age cohort [1,2]. Research shows this group also has higher rates of infectious diseases [3, 4] and respiratory disorders [5, 6]. Pandemics like that caused by COVID-19 may thus further increase morbidity and mortality for people with psychiatric disabilities. Of further concern, prevention practices necessary to avoid infection lead to stress and social isolation. Psychiatric disabilities are often defined by a stress vulnerability; i.e., the mental illness of people with serious psychiatric conditions are likely exacerbated by genetically endowed hyper-sensitivity to stress $[7,8]$. These are further worsened when people are distanced from their support system [9]. Hence, COVID-19 practices related to staying safe may exacerbate existing mental health symptoms [10]. Therefore, people with psychiatric disabilities must address three key questions to withstand the pandemic. First, what precautions should people take to avoid infection? (remaining safe) Second, what kind of a clinical care should individuals who are positive for

P. W. Corrigan $(\bowtie) \cdot$ K. Nieweglowski

Illinois Institute of Technology, Chicago, USA

e-mail: corrigan@iit.edu

K. Nieweglowski

e-mail: knieweg1@iit.edu the virus pursue? (dealing with infection) Third, what resources might people pursue to promote wellness and mental health? (treating mental illness).

Research has identified several factors that account for this worsened pattern of health with absence of health literacy; namely, people with psychiatric disabilities are frequently unaware of the breadth and depth of symptoms related to mental and physical illness, evidence-based treatments to impact these illnesses, and practical strategies to engage in these treatments [11, 12]. Promoting health literacy is even more difficult when standards for prevention and practice rapidly evolve or are provided in confusing ways that undermine confidence in making appropriate health decisions [13]. This is especially problematic in many countries where elected officials are using the pandemic to promote personal political agenda rather than public health.

Psychoeducational programs have been developed to enhance health literacy and corresponding health and wellness behavior; namely, teaching people how to make sense of mental and physical health symptoms and corresponding evidence-based interventions $[14,15]$. Psychoeducational programs are adapted to address the cognitive and social disabilities that undermine skill learning $[16,17]$. Hence, psychoeducational programs are needed to help people answer the three key questions. 


\section{Peer Program Facilitators}

Peers with lived experience of recovery from serious mental illness have an important and unique role in psychoeducational programs specifically as program facilitators. A comprehensive review of research on the impact of peer services uncovered nine randomized controlled trials [18]. Findings showed peer psychoeducation led to improvement in a variety of personal goals of psychiatric service recipients [19-26] with two studies specifically showing positive impact of peer psychoeducation on the health and wellness goals of this population [14, 15]. Empirical research [27-29] and consensus statements [30, 31] suggested key ingredients to peerness including disclosure related to hope and exposure to vulnerability; modeling based on the peer's journey; and trust that emerges from shared experience. Note that increased trust is especially important for promoting COVID-19 literacy given frequently uncertain health messages.

Pandemics are filling us all with uncertainty and desperation. Peer supporters once again become a major resource for promoting hope and empowerment. Rehabilitation providers need to specifically determine how peer providers can develop and implement curricula that help the person manage staying safe, dealing with infection, and treating mental illness.

\section{References}

1. Colton CW, Manderscheid RW. Congruencies in increased mortality rates, years of potential life lost, and causes of death among public mental health clients in eight states. Prev Chronic Dis. 2006;3(2):1-14.

2. Saha S, Chant D, McGrath J. A systematic review of mortality in schizophrenia: is the differential mortality gap worsening over time? Arch Gen Psychiatry. 2007;64:1123-31.

3. Cournos F, McKinnon K, Sullivan G. Schizophrenia and comorbid human immunodeficiency virus or hepatitis $\mathrm{C}$ virus. J Clin Psychiatry. 2005;66(SUPPL. 6):27-33.

4. Robson D, Gray R. Serious mental illness and physical health problems: a discussion paper. Int J Nurs Stud. 2007;44(3):457-66.

5. Partti K, Vasankari T, Kanervisto M, Perälä J, Saarni SI, Jousilahti $\mathrm{P}$, et al. Lung function and respiratory diseases in people with psychosis: population-based study. Br J Psychiatry. 2015;207(1):37-45.

6. Wu Q, Dalman C, Karlsson H, Lewis G, Osborn DPJ, Gardner R, et al. Childhood and parental asthma, future risk of bipolar disorder and schizophrenia spectrum disorders: a population-based cohort study. Schizophr Bull. 2019;45(2):360-8.

7. Goh C, Agius M. The stress-vulnerability model how does stress impact on mental illness at the level of the brain and what are the consequences? Psychiatr Danub. 2010;22(2):198-202.

8. Rudnick A, Lundberg E. The stress-vulnerability model of schizophrenia: a conceptual analysis and selective review. Curr Psychiatry Rev. 2012;8(4):337-41.

9. Kawachi I, Berkman LF. Social ties and mental health. J Urban Heal. 2001;78(3):458-67.

10. Druss BG. Addressing the COVID-19 pandemic in populations with serious mental illness. JAMA Psychiatry. 2020. https://doi.org/10.1001/jamapsychiatry.2020.0894.

11. Jorm AF. Mental health literacy; empowering the community to take action for better mental health. Am Psychol [Internet]. 2012 Apr [cited 2020 May 11];67(3):231-43. http://www.ncbi.nlm.nih.gov/pubmed/22040221.

12. Jorm AF. Why we need the concept of "mental health literacy." Health Commun [Internet]. 2015 Dec 2 [cited 2020 May 11];30(12):1166-8. http://www.ncbi.nlm.nih.gov/ pubmed/26372027.

13. Calnan M, Rowe R. Researching trust relations in health care: conceptual and methodological challenges-an introduction. J Health Organ Manag. 2006;20(5):349-58.

14. Brekke JS, Siantz E, Pahwa R, Kelly E, Tallen L, Fulginiti A. Reducing health disparities for people with serious mental illness. Best Pract Ment Health. 2013;9:62-82.

15. Druss BG, Zhao L, von Esenwein SA, Bona JR, Fricks L, Jenkins-Tucker $S$, et al. The Health and Recovery Peer (HARP) Program: a peer-led intervention to improve medical self-management for persons with serious mental illness. Schizophr Res. 2010;118(1-3):264-70.

16. Ahuir M, Cabezas Á, Miñano MJ, Algora MJ, Estrada F, Solé M, et al. Improvement in cognitive biases after group psychoeducation and metacognitive training in recent-onset psychosis: a randomized crossover clinical trial. Psychiatry Res [Internet]. 2018 Dec 1 [cited 2020 May 11];270:720-3. http://www.ncbi.nlm.nih.gov/pubmed/30551315.

17. Dubreucq J, Ycart B, Gabayet F, Perier CC, Hamon A, Llorca PM, et al. Towards an improved access to psychiatric rehabilitation: availability and effectiveness at 1-year follow-up of psychoeducation, cognitive remediation therapy, cognitive behaviour therapy and social skills training in the FondaMental Advanced Centers of Expertise-Schizophrenia (FACE-SZ) national cohort. Eur Arch Psychiatry Clin Neurosci. 2019;269(5):599-610.

18. Corrigan PW, Michaels PJ, Vega E, Gause M, Larson J, Krzyzanowski R, et al. Key ingredients to contact-based stigma change: a cross-validation. Psychiatr Rehabil J. 2014;37(1):62-4.

19. Clarke GN, Herinckx HA, Kinney RF, Paulson RI, Cutler DL, Lewis K, et al. Psychiatric hospitalizations, arrests, emergency room visits, and homelessness of clients with serious and persistent mental illness: findings from a randomized trial of two ACT programs vs. usual care. Ment Health Serv Res. 2000;2(3):155-64.

20. Davidson L, Shahar G, Stayner DA, Chinman MJ, Rakfeldt J, Tebes JK. Supported socialization for people with psychiatric disabilities: Lessons from a randomized controlled trial. J Community Psychol [Internet]. 2004 Jul 1 [cited 
2020 May 11];32(4):453-77. http://doi.wiley.com/10.1002/ jcop. 20013.

21. Goldberg RW, Dickerson F, Lucksted A, Brown CH, Weber E, Tenhula WN, et al. Living Well: an intervention to improve self-management of medical illness for individuals with serious mental illness. Psychiatr Serv. 2013;64(1):51-7.

22. Griswold KS, Servoss TJ, Leonard KE, Pastore PA, Smith SJ, Wagner C, et al. Connections to primary medical care after psychiatric crisis. J Am Board Fam Pract [Internet]. 2005 May [cited 2020 May 11];18(3):166-72. Available from: http://www.ncbi.nlm.nih.gov/pubmed/15879563.

23. Griswold KS, Homish GG, Pastore PA, Leonard KE. A randomized trial: Are care navigators effective in connecting patients to primary care after psychiatric crisis? Community Ment Health J [Internet]. 2010 Aug [cited 2020 May 11];46(4):398-402. http://www.ncbi.nlm.nih.gov/pubmed/ 20204511.

24. O’Donnell M, Parker G, Proberts M, Matthews R, Fisher D, Johnson B, et al. A study of client-focused case management and consumer advocacy: the community and consumer service project. Aust New Zeal J Psychiatry [Internet]. 1999 Oct [cited 2020 May 11];33(5):684-93. http://www.ncbi. nlm.nih.gov/pubmed/10544992.

25. Sledge WH, Lawless M, Sells D, Wieland M, O'Connell MJ, Davidson L. Effectiveness of peer support in reducing readmissions of persons with multiple psychiatric hospitalizations. Psychiatr Serv [Internet]. 2011 May [cited 2020
May 11];62(5):541-4. http://www.ncbi.nlm.nih.gov/ pubmed/21532082.

26. Solomon P, Draine J, Delaney MA. The working alliance and consumer case management. J Ment Health Adm [Internet]. 1995 Mar [cited 2020 May 11];22(2):126-34. http:// www.ncbi.nlm.nih.gov/pubmed/10142126.

27. Davidson L, Chinman M, Sells D, Rowe M. Peer support among adults with serious mental illness: a report from the field. Schizophr Bull. 2006;32:443-50.

28. Solomon P. Peer support/peer provided services underlying processes, benefits, and critical ingredients. Psychiatr Rehabil J. 2004;27(4):392-401.

29. Walker G, Bryant W. Peer support in adult mental health services: a metasynthesis of qualitative findings. Psychiatr Rehabil J. 2013;36(1):28-34.

30. Substance Abuse and Mental Health Services Administration (SAMHSA). Core competencies for peer workers in behavioral health services. [Internet]. 2015. https://www. samhsa.gov/sites/default/files/programs_campaigns/brss_ tacs/core-competencies.pdf.

31. Substance Abuse and Mental Health Services Administration (SAMHSA). Who are peer workers? [Internet]. 2019. https://store.samhsa.gov/system/files/sma09-4454.pdf.

Publisher's Note Springer Nature remains neutral with regard to jurisdictional claims in published maps and institutional affiliations. 